\title{
PREPARATION OF LIQUID BIO-FERTILIZERS OF PLANT SOURCES AND THEIR EFFECT ON PLANT GROWTH
}

\author{
${ }^{1}$ H.B. Waghire, 1S.A. Patil, ${ }^{2}$ S.M. Baraskar, ${ }^{3}$ K.K. Kharnar and ${ }^{3}$ S.S. Sanap \\ ${ }^{1}$ MJS Mahavidyalaya Shrigonda \\ 2Jamkhed Mahavidyalaya Jamkhed \\ ${ }^{3}$ SSGM College, Kopargoan \\ *Corresponding Author: hbwaghire@gmail.com
}

Communicated: 17.07 .2020

Revision : 19.07.20 \& 10.8.2020

Accepted: 26.08 .2020

Published: 30.09 .2020

\begin{abstract}
:
In this paper preparation of liquid bio-fertilizer of plant sources and their effect on plant growth by using Moringa leaf, Banana peel and Aloe vera juice. For preparation of liquid bio-fertilizers by fermentation process (Satish Mohod) different parameters like the plant height, $\mathrm{pH}$, stress condition, seed germination percentage, and chlorophyll content etc have studied and all parameters showed the significant result.
\end{abstract}

Key words: - Liquid extract, $p H$, chlorophyll Content, stress condition, fermentation.

\section{INTRODUCTION:}

Bio fertilizer is a substance which contains living microorganism which, when applied to seed, plant surface or soil colonizes the rhizosphere or the interior of the plant promotes growth by increasing the supply or availability of primary nutrients. Fertilizers directly increase soil fertility by adding nutrient. Bio fertilizer add nutrients through the natural processes of fixing atmospheric nitrogen solubilising phosphorous and stimulating plant growth through the synthesis of growth promoting substance. Liquid bio fertilizers are suspension having agriculturally useful microorganisms, which fix atmospheric nitrogen and solubilise insoluble phosphate and make it available for the plant. Liquid bio fertilizer formation is the promising and updated technology which in spite of many advantages over the agrochemicals left the considerable dispute among the farmer community in terms of several reasons, major being the viability of the organisms. Liquid biofertilizers increasingly available in the market as one of the alternatives to chemical fertilizers and pesticides. Bio-fertilizers add nutrients through the natural process of fixing atmospheric nitrogen, solubilising phosphorous and stimulating plant growth through the synthesis of growth promoting substances. They can be categorised in different ways based on their nature and function, one simple broadly disseminated classification is as follow

* Nitrogen bio-fertilizer.

* Phosphorous bio-fertilizer.

* Compost bio-fertilizer.

Soil is natural habitat of variety of agriculturally beneficial microorganism certain soil microorganism have and an ability to absorb 
and convert atmospheric nitrogen to the readily available from to the plant where as certain soil microorganism solubilise part of the bound phosphate of the soil and thereby make them available to the plants .both these attributes make them important to be used as bio fertilizer .microorganism employed to improve availability of nutrients, viz, nitrogen by N2phosphorous(by solubilizing soil phosphorous), to the crops are called as bio fertilizer the various microorganism having realized/prospective application as biofertilizer are bacteria (rhizobium spp, azospirillium, azatobacter) Fungi (microrhizea like glomous), blue -green algae or cynobacteria (anabena, nostoc etc.) and azolla (a fern containing anabena azallae biofertilizer are product of elected valuable live microorganism, which help to improve plant growth and productivity mainly through supply of plant nutrients biofertilizers are also known as microbial inoculants or bio inoculants (Chan Alexander,1973; Moffett et.al .1983).

Synthetic/chemical manure not only provide essential nutrients to food crops but also provide simply available manner .so these fertilizers can rapidly improve increase and efficiency of food crops an and or quick to gain popularly, however broad use of such fertilizer leads to serious concern .nitrate leakage and exterior / soil water toxic waste due to the augmented use of fertilizer is straight linked to human health problems. Likewise, fresh water pollution through chemical fertilizer /fertilizer remains be single of the main cause of eutrophication. Organisms to be often use while bio-fertilizer component be nitrogen fixers $(\mathrm{N}$ fixer), potassium solubilises by the formulation of mold and fungi. Nearly all of the bacteria included in bio fertilizers included close association through plants roots.

The rhizobium has symbiotic interaction by legume roots and rhizo bacteria in habit on roots surface or in rhizosphere soil. The phosphorous available to the plant. (Gupta, 2004).

A number of reports included examine the different bacterial species to solubilizer insoluble organic phosphate compounds, such as tricalcium phosphate, dicalcium phosphate, hydroxyapatite and rock phosphate. Among

bacterial genera with the capacity are pseudomonas, bacillus rhizobium. Burkholderia Achromobacter, Agrobacterium, micrococcus, Azetobacter, flavobacterium and Erwina. There are considerable population of phosphate.

Solubilising bacteria in soil and in plant rhizosphere (Wani \& Lee 2002).

The presence study of research how the liquid bio fertilizers are important to the plant and how they are affected plant. For detailed study the plant height,stress condition effect, $\mathrm{pH}$ ,chlorophyll content and seed germination percentage had studied in detail.

\section{MATERIAL AND METHOD (SATISH MOHOD)}

\section{Material:}

For the study banana peel powder $50 \mathrm{gm}$, Moringa leaf powder $50 \mathrm{gm}$ and Aloe vera pulp $250 \mathrm{ml}$, yeast, distilled water, tray, soil, seed, autoclave, muslin cloth $\mathrm{p}^{\mathrm{H}}$ indicator were taken.

\section{Method:}

Prepare the sample of banana peel powder and moringa leaf powder with the help of oven at $70^{\circ} \mathrm{C}$ for $5 \mathrm{hrs}$. Take a two beaker of $1000 \mathrm{ml}$. In one beaker add in $500 \mathrm{ml}$ distilled water and add 50 gm of Moringa leaf. In second beaker 500 $\mathrm{ml}$ distilled water and add 50 gm of Moringa leaf 
incubate in 3 to 4 day for well mixing After the mixing filter with muslin cloth. Measure the filtrate $300 \mathrm{ml}$ banana peel 250 gm Moringa leaf and $250 \mathrm{ml}$ Aloe vera juice $\mathrm{mix}$ in beaker and autoclave for $20 \mathrm{~min}$. After the sterilization add a $10 \mathrm{gm}$ of yeast and incubate the 5 to 7 days. Used directly when no storage. After the fermentation or prepare sample extract and use it for checking parameter. Take a 20-maize seed and wheat seed for checking growth parameter. Take two plots one plots maize and wheat for control for each. After the growing seed spray for liquid bio fertilizer in one plot and one remaining as it is weight of sample Moringa and banana peel powder 3, 4 days well mixing fermentation.

\section{OBSERVATIONS}

Before the treatment the length of wheat plant was the 6.5 and maize was the 2.3. After treatment: $2^{\text {nd }}$ day Wheat 6.5- 7, Maize 2.32.6,4th day Wheat $6.5-8.5$ Maize $45 .-6,5^{\text {th }}$ day Wheat 6.5- 8.6, Maize $5.5-7,8^{\text {th }}$ day Wheat 7.58.9, Maize 9.6- 10.6

Stress condition: When water supply stop after 10 days to maize and wheat plant then effect on control plant is shrink and in liquid bio fertilizer treatment plant there is no effect. Showed that water stress reduced significantly the absorption of nitrogen; phosphorous and potassium by plant, also total pigment and total chlorophyll accumulation were reduced height is decrease in control plant after stop the water. no change height in treatmented plant.

\section{Chlorophyll estimation}

Weight $5 \mathrm{gm}$ of leaf put in mortar pastel grind the tissue of fine pulp with addition of $80 \%$ acetone, Centrifuge and transfer the supernatant of volumetric flask. Grind the tissue residue with $20 \mathrm{ml}$ of $80 \%$ acetone centrifuge and transfer the supernatant to same volumetric flask Repeat the procedure until the residue colourless wash the mortar and pestle through with $80 \%$ acetone and collect the sample. Read the absorbance of solution at 645 and $663 \mathrm{~nm}$, against the solvent $80 \%$ acetone as a blank.

\section{RESULT AND CONCLUSION:}

Before the treatment the length of wheat plant was 6.5 and maize were 2.3. After the treatment wheat and maize plant height is highly increased than the control plant. After the $8^{\text {th }}$ day in control condition the maize is 9.6 and wheat is 7.5. Treatment plant height maize is 10.6 and wheat is 8.9. In this project before treatment $\mathrm{pH}$ is 8.0 and after treatment $8.5 \mathrm{pH}$ which is more basic than before treatment 10\% more germination percentage in treatment condition than the control in maize and in wheat 5\% more germination percentage in treatment than the control. In this paper control plant chlorophyll pigment is $0.260,0.340$ and treatment plant is 0.066 and $0.345 \mathrm{~nm}$. In this project 10 days stress condition observed in control condition plant height decrease. Treated plant shows no change in height.

\section{ACKNOWLEDGEMENT:}

Authors are thankful to Principal SSGM College Kopargaon, for providing the facility for research work authors are also thankful to head dept. of Botany SSGM College for providing facility for the research work and authors are thankful to principal MJS College Shrigonda for preparation of the manuscript and inspiration during whole research work.

REFERENCE: 
Adam SM, Abdalla AM,Risk FA,2002.effect of the interaction between the mineral and biofertilizers on the productivity of cantaloup (Cucumist melo L,) under the newly reclaimed soil condition.Egypt.J.Hort 29:301-315.

Barik A.K and Goswami,A.2003 Efficiency of biofertilizers with nitrogen levels on growth,productivity and economy in wheat.Indian J.Agron., and economy in wheat.Indian J.Agron. 44(2):100-102.

Bahadur,A.,Singh J., Singh K .P. and Rai, M.(2006).plant growth yeild and quality attributes of garden pea as influenced by organic amendments and biofertilizers.Indian J.Hort., 63(4):464-466.

Karun KS, 2007. Biofertilizers for sustainable agriculture. mechanism of psolubilization sixth edition, Agribios publishers. Jodhpur. Indian. Pp.196197.

Hasarin Ngampimol and vigada kunathigan (2008) study of shelf life for liquid biofertilizers from vegetables faculty of biotechnology. Assumption university bangkok Thailand 11(4):204-208.

Thamizh Vendon, R. and Thangaraja, M. 2007, standardization of dosage of liquid cyst formulation of Azospirillum for different applications methods, acto Agronomica Hyngarica 55(4):475-484
T.M.Abdel .Ghany, M.M.Alawlagi and M.A.Al Abbound (2013) role of biofertilizers in agriculture: a brief review mycopah $11(2): 95-101$

Vessey, J.K. (2013) plant growth promoting rhizobacteria as biofertilizers plant soil 2 55 :571-586.

Mishra D.J., (2013) Role of bio-fertilizer in organic agriculture. A review research journal science vol.2(JSC),39-41

Sumita Pal, H.B. Singh, Alvina famoqui and Amitava Rakshit-fungal biofertilizers in Indian agriculture: perceptions, demand and promotion journal of Eco-friendly agriculture 10(2):101-113.

Morajdhwaj Singh, S.K. Biswas,Devesh Nagar, krishan Lal and Jaskaran singh (2017), Impact of biofertilizers on growth parameter and yeild of potato ,international journal of current microbiology and applied science ISSN:2319-7706 volume 6 number 5 up 1717-1724.

B.H Panchal, V.K. Patel, K.P. Patel and R.A. khimani (2018) effect of biofertilizers organic manures and chemical fertilizers on microbial population yeild and yield attributes and quality of sweetcorn (Zea maize L., saccharate. 